\title{
Surfaces
}

INTRODUCTION TO ANDREAS KABLITZ'S RENAISSANCE REBIRTH: SOME REMARKS ABOUT THE HUMANISTIC INTERPRETATION OF HISTORY

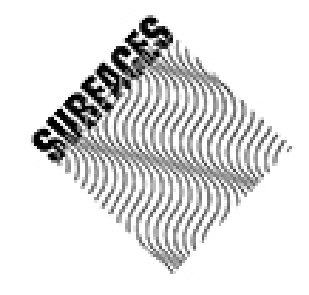

\section{Ernst Behler}

Volume 9, 2001

TROISIÈME CONGRÈS INTERNATIONAL SUR LE DISCOURS

HUMANISTE. LA RÉSISTANCE HUMANISTE AU DOGMATISME

AUJOURD'HUI ET À LA FIN DU MOYEN ÂGE

THIRD INTERNATIONAL CONFERENCE ON HUMANISTIC

DISCOURSE. HUMANISTIC RESISTANCE TO DOGMATISM TODAY

AND AT THE END OF THE MIDDLE AGES

URI : https://id.erudit.org/iderudit/1065067ar

DOI : https://doi.org/10.7202/1065067ar

Aller au sommaire du numéro

\section{Éditeur(s)}

Les Presses de l’Université de Montréal

\section{ISSN}

1188-2492 (imprimé)

1200-5320 (numérique)

Découvrir la revue

Citer ce document

Behler, E. (2001). INTRODUCTION TO ANDREAS KABLITZ'S RENAISSANCE REBIRTH: SOME REMARKS ABOUT THE HUMANISTIC INTERPRETATION OF HISTORY. Surfaces, 9. https://doi.org/10.7202/1065067ar

\section{Résumé de l'article}

Dans le cadre du troisième congrès international sur le discours humaniste, le texte propose une introduction à « Renaissance-Rebirth: Some Remarks about the Humanistic Interpretation of History » d'Andreas Kablitz et rapporte les principaux enjeux qui ont été l'objet de discussions. 


\section{INTRODUCTION TO \\ ANDREAS KABLITZ'S \\ RENAISSANCE - \\ REBIRTH: SOME \\ REMARKS ABOUT THE \\ HUMANISTIC \\ INTERPRETATION OF \\ HISTORY}

Ernst Behler

Surfaces vol IX 101.7 (v1.0a - 15.12.2001) - ISSN:

1188-2492

Tout texte reste la propriété de son auteur. Néanmoins, SURFACES demande d'être citée à l'occasion de toute autre publication du texte en question.

\section{ABSTRACT \\ In the context of the Third International \\ Conference on Humanistic Discourse, this text introduces Andreas Kablitz's « Renaissance- \\ Rebirth : Some Remarks about the Humanistic Interpretation of History » and reports on the central concerns that emerged in its discussion.}

\section{RÉSUMÉ}

Dans le cadre du troisième congrès international sur le discours humaniste, le texte propose une introduction à « Renaissance-Rebirth : Some Remarks about the Humanistic Interpretation of History » d'Andreas Kablitz et rapporte les principaux enjeux qui ont été l'objet de discussions. 
In his contribution to the Conference, Andreas Kablitz (Cologne) historicized concepts such as humanism, rebirth, Renaissance, resistance to dogma and ideology concepts on which the Munich conference of 1996 was organized. By placing the term humanism into the specific historical culture in which it originated, i.e., the fifteenth and sixteenth centuries, he intends to make us aware that the particular note we attach to humanism is programmatic, a "strategy of self-legitimation by reference to an unspecified past." Resistance to dogma and ideology is more characteristic of those forms of humanism, which originated during the nineteenth and twentieth centuries, whereas during the period of Renaissance humanism, resistance to dogma and authority had a different trend. To be sure, humanists of that time were vehemently critical of scholasticism and clerical authority, but their interest in classical literature derived from an interest in truth, and classical literature assumed a function of authority for them. By relating resistance to dogma to these earlier centuries, a "hermeneutic usurpation" of a different historical culture takes place. Since a systematic legitimation is not possible and not suitable for self-legitimation, the past becomes attractive for the foundation of legitimacy and inspires what Kablitz calls a "strategy of self-legitimation to an unspecified past." More specifically, he deals with the notion of rebirth which indeed is a central concept in the self-interpretation of the sixteenth century as well as of the historical interpretation of the nineteenth century when the term "Renaissance" originated. Renaissance is seemingly a quotation, since fifteenth and sixteenth century humanists used the term rinascita to interpret their epoch. Yet their use of rinascita differs essentially from the meaning given to the Renaissance by nineteenth century historians.

Kablitz illustrates this difference on the basis of two prominent texts - Giorgio Vasari's Preface to his famous Vite, his portraits of great painters, sculptors, and architects of his time (1550), which contains the most condensed systematic theory of rebirth; and the volume on the Renaissance in Jules Michelet's comprehensive HistoiredeFrance (1833-1866). Vasari's notion of rebirth is limited to art and establishes a relationship between art and creation that had been the model of Christian thinking about art during the Middle Ages and had replaced the ancient relationship between art and nature. The metaphorical concept for Vasari's view of this relationship between art and creation and the artist 
as creator is the notion of "deus artifex." Neglecting all classical authors, he turns to the biblical myth of creation as the primary model for art. Yet he rewrites this myth under the impact of the philosophical trends of the later Middle Ages. His view of creation is no longer determined by forms and ideas of creation - images, which precede the act of creation. Kablitz interprets this transformation as a result of nominalism in the late Middle Ages. The preexistence of ideas was excluded in order to avoid limiting the creator's power, to fully recognize God's omnipotence, which would have been restricted by pregiven ideas. In order to safeguard the creator's power, other representatives of nominalism considered the number of pregiven forms as infinite and by analogy, also applied the infinite number of ideas to the human mind (Nicholas of Cusa). Vasari, however, totally abandoned the assumption of ideas and viewed creation as "an entirely contingent, autoreferential act of God" and, by analogy, interpreted the human artist's creation according to this model. Kablitz illustrates this model by Vasari's notion of modello. Modello no longer relates to an image preceding creation, but, in an almost inverted way, refers to the formless matter out of which the artist creates his work. This theory of art thereby leads to a renunciation of a creatio ex nihilo which is replaced by an image of an artist who is successively improving his work, to a notion of art as gradual production, opening the dimension of time and history. Time, however, can be interpreted as a dimension of perfection as well as a process of decline. The idea of a rebirth reconciles both views of the history of art. This process of decline began in the Roman Empire, before the invasion of the barbarians, and reached its climax in the "perversion of art in the Middle Ages." The early Christians are no longer viewed as witnesses of redemption, but as contributors to the annihilation of art. A transformation from ethics to art is taking place. The history of salvation is transformed into a history of art. The idea of rebirth is released from its Christian connotations and indicates an overcoming of the constant decline of art. Rinascita, however, is not repeatable and cannot be interpreted as a return to the origin. The notions of origin and imitation can no longer serve as a model of art and are indeed replaced by the images of God's creation and human art. God's creation remains superior to human art, but human art no longer bears the burden of its mythic origin and a return to it.

In Kablitz's view, Michelet's conception of the Renaissance differs from Vasari's rinascita. Michelet does not view rebirth as an unrepeatable moment or a transcendent intervention, but relates it to the historical 
connotations of the term. History is the realm of selfconstitution, and the sixteenth century is "un héros." History is also the "intelligence of life," referring to reason and justice. The man of the Renaissance has studied his nature and established himself on the grounds of reason and justice. The criterion for this type of naturalness derives from the classical culture of the ancients, while the clergy of the Middle Ages represents the radical suppression of nature. I pass over the discussion of the ideas of an "archive of the past" and its role in the rediscovery of the ancients which finds its correspondence in the invention of print in the age of the Renaissance. To justify the contingent course of history, Michelet refers to the idea of progress in the Enlightenment, although he concedes the long and effective resistance of the Middle Ages by its suppression of nature. His notion of life attempts to reconcile these two conflicting views and leads to a biological interpretation of history. Yet his naturalization of history opens up another conflict with the status of culture. The status of culture is a prerequisite for the work of historians and historical research. As in the case of medieval scholasticism, culture, especially in the form of "school," can be seen as a counter-concept to nature and life. In this sense, the Middle Ages were an artificial epoch for Michelet. Historical research creates an archive and thwarts life, produces the contradiction of res gestae and historia rerum gestarum. At the same time, history, archive, and school are indispensable for the preservation of life and nature. The artificiality of the medieval culture, of scholasticism, occurred because of forgetfulness, the lack of historical memory, and the oblivion of an historical tradition. Michelet's image of the Renaissance resolves all of these contradictions and thereby assumes an emblematic character for his conception of history. The Renaissance is seen as a symbiosis between cultural restitution on the one hand, and as natural rebirth on the other, as old and young at the same time, an "age of science and of childhood." The Renaissance assumes the proportions of a universal program of history and leaves behind Vasari's conception of rinascita as related to art. The Renaissance is an age of the discovery of truth, of an eruption of life, and not merely a period of art history.

The basic difference between Vasari's and Michelet's conceptions of rebirth thus reveals itself as the difference between perfection and truth. Perfection requires production, truth requires knowledge. The last section of the discussion turns to the implications of this type of difference with regard to the formation of a humanistic discourse today, the difference between 
creating such a discourse on the one hand, and the critical knowledge of all prerequisites, including tradition, for such a discourse on the other. In our dealing with this problem, as Kablitz sees it, we seem to favor all forms of archive, memory, and critical analysis over a resolute effort to shape such a discourse and to relate it to the future. This attitude is combined with a general skepticism concerning the possibility of determining a definite truth of man and a concern, or a fear, about the dangers inherent in all efforts to shape the future. Culture is thereby defined as a work of memory, which guarantees the absence of cultural violence. The definition of humanism retreats from all efforts to shape the future. However, contributing an answer to the unresolved problem of defining the relationship between past and future remains an important task for the humanistic discourse of today.

\section{Roundtable Discussion}

\section{Summary}

Ernst Behler
Hendrik Birus
Jacques Derrida
Wolfgang Iser
Andreas Kablitz
Murray Krieger
Jan-Dirk Müller
Rainer Warning

The discussion focused on specific themes of this broad array of problems and emphasized the importance of the difference between Vasari and Michelet in their articulation of a humanistic discourse (H. Birus). J. Derrida problematized the relationship between humanism and vitalism, the challenge of nature in the name of the tradition and the challenge of the tradition in the name of nature. Another point of interest was the idea of the artist as creator and the different types of art theory that evolve from the Renaissance conception of a god-like creator and the nineteenth century view of art as self-representation (M. Krieger). R. Warning debated the notion of temporality in Vasari's conception of creation and related it to the concept of a creatio perpetua, whereas $\mathrm{W}$. Iser specified the term temporality from a historicist perspective. Another important aspect brought up during the discussion was the relationship 
between creation and technology (J.D. Müller). This was the session that opened the Munich conference and was followed by Jan-Dirk Müller's presentation of "Ambivalences of Humanist Resistance to Dogma."

Accueil Surfaces | Table des matières | Recherche Surfaces Home Page | Table of Contents | Search

PUM | Livres | Revues | Publications électroniques | Vente et distribution 